\begin{tabular}{|l|l|l||}
\hline \multicolumn{2}{|c|}{ PublisherInfo } \\
\hline \hline PublisherName & $:$ & BioMed Central \\
\hline \hline PublisherLocation & $:$ & London \\
\hline \hline PublisherImprintName & $:$ & BioMed Central \\
\hline \hline
\end{tabular}

\title{
Genomic workout in Parkinson disease
}

\begin{tabular}{|l|l|l||}
\hline \multicolumn{2}{|c|}{ ArticleInfo } \\
\hline \hline ArticleID & $:$ & 4252 \\
\hline \hline ArticleDOI & $:$ & $10.1186 /$ gb-spotlight-20011115-01 \\
\hline \hline ArticleCitationID & $:$ & spotlight-20011115-01 \\
\hline \hline ArticleSequenceNumber & $:$ & 323 \\
\hline \hline ArticleCategory & $:$ & Research news \\
\hline \hline ArticleFirstPage & $:$ & 1 \\
\hline \hline ArticleLastPage & $:$ & 3 \\
\hline \hline & $:$ & RegistrationDate : 2001-11-15 \\
ArticleHistory & $:$ & OnlineDate $\quad$ 2001-11-15 \\
\hline \hline ArticleCopyright & $:$ & BioMed Central Ltd2001 \\
\hline \hline ArticleGrants & $:$ & \\
\hline \hline ArticleContext & $:$ & 130592211 \\
\hline \hline
\end{tabular}




\section{Tudor Toma}

Email: t.toma@ic.ac.uk

Idiopathic Parkinson disease (PD) is a neurodegenerative condition in which the involvement of genes and the environment is still controversial. Two papers in the November 14 issue of JAMA from Duke University Medical Center, Durham, USA suggest that the parkin gene is important in early-onset PD and that multiple genetic factors are important in the development of late-onset PD.

Scott et al. performed a complete genomic screening in 174 families (870 individuals) that have multiple individuals diagnosed as having idiopathic PD. Genotyping was performed by the FAAST method. They detected significant evidence for linkage to chromosome 6 (parkin gene) in families that have at least 1 individual with PD onset at younger than 40 years. The linkage with chromosomes 17q, $8 \mathrm{p}$, and $5 \mathrm{q}$ was significant in families with late-onset $\mathrm{PD}$, by contrast. In addition, chromosome $9 \mathrm{q}$ was linked to families that include both levodopa-responsive and levodopa-nonresponsive patients (JAMA 2001, 286: 2239-2244).

"This finding suggests a possible mechanistic connection between levodopa-resistant Parkinsonism and dystonia", said Maria Grazia Spillantini and Michel Goedert from the Centre for Brain Repair and Department of Neurology, University of Cambridge, UK, in an accompanying editorial.

In a second paper, Martin et al., from the same group, looked for single-nucleotide polymorphisms in the tau gene in a total of 1056 individuals from 235 families with PD. They found evidence that implicates tau, which encodes a microtubule-associated protein, as a susceptibility gene for idiopathic late onset PD (JAMA 2001, 286:2245-2250).

"Further studies to identify the molecular pathways affected by the responsible genes will provide valuable insight into this complex etiology and potential treatment for PD" wrote Margaret PericakVance, Director of the Duke Center for Human Genetics.

\section{References}

1. Duke University Medical Center, [http://www.mc.duke.edu/]

2. Scott WK, Nance MA, Watts RL, Hubble JP, Koller WC, Lyons K, Pahwa R, Stern MB, Colcher A, Hiner BC, et al:: Complete genomic screen in Parkinson disease: evidence for multiple genes. JAMA 2001, 286: 2239-2244., [http://jama.ama-assn.org/issues/v286n18/rfull/joc 10904.html] 
3. Centre for Brain Repair, [http://www.brc.cam.ac.uk/]

4. Spillantini MG and Goedert M: Tau and Parkinson disease. JAMA 2001, 286:2324-2326., [http://jama.ama-assn.org/issues/v286n18/ffull/jed10073.html]

5. Martin ER, Scott WK, Nance MA, Watts RL, Hubble JP, Koller WC, Lyons K, Pahwa R, Stern MB, Colcher A, et al.: Association of single-nucleotide polymorphisms of the tau gene with late-onset Parkinson disease. JAMA 2001, 286:2245-2250., [http://jama.ama-assn.org/issues/v286n18/abs/ joc 10905.html]

6. Duke Center for Human Genetics, [http://wwwchg.mc.duke.edu/] 